\title{
INKUBASI TITONIA PADA TANAH SAWAH TERHADAP ASAM-ASAM ORGANIK
}

\author{
Gusnidar, Nurhajati Hakim dan Teguh Budi Prasetyo \\ J urusan Tanah F akultas Pertanian U niversitas Andalas
}

\begin{abstract}
The research about "Incubation of titonia for organic acid production in rice field" has been conducted in soil laboratory Agriculture Collage Andalas University Padang, since January to August 2005. The objective of this research was to determine the best method of using titonia to produce organic acids in rice field. The research had 2 factors, 3 series of titonia application and 5 levels of titonia dossages with 3 replications. The series are: $A_{1}=$ Titonia was mixed with soil and then, the soil was directly flooded; $\mathrm{A}_{2}=$ Titonia was mixed with soil and then, let them stay on soil surface for 3 weeks before being flooded; $A_{3}=$ Titonia was mixed with soil and then, the soil was moistened until field capacity for 3 weeks before being flooded. The second factor was titonia dossages $(0,000 ; 1,250 ; 2,500 ; 3,750 ; 5,000 \mathrm{~g}$ dry weight of titonia per $\mathrm{kg}$ soil). The result showed that organic acids of the soil had been changed as a consequence of titonia application and the incubation with soil. The highest organic acid production was found at combination of titonia incubation with soil at field capacity for 3 weeks, that was malat acid (184-489 $\left.\mathrm{mgl}^{-1}\right)$. The others detected were citrate, tartarate, malate, and benzoat acids, butt fenolate acids was not detected.
\end{abstract}

Keywords: incubation, organic acids, rice field, titonia.

\section{PENDAHULUAN}

Bahan organik (BO) seperti hasil pangkasan titonia, mampu meningkatkan kesuburan tanah melalui perbaikan sifat fisika, kimia dan biologi tanah. Peranan BO terhadap sifat kimia tanah diantaranya dapat meningkatkan kapasitas tukar kation (KTK), dan karbon (C) tanah serta melarutkan sejumlah unsur hara dari mineral oleh asam organik (AO) (Rao, 1994). Keefektifan AO dalam degradasi mineral tergantung pada konsentrasi dan reaktivitas kimia asam. Dalam konsentrasi rendah, asam fulvat (AF) dan asam humat $(\mathrm{AH})$ yang dihasilkan $\mathrm{BO}$ lebih berperan penting daripada $\mathrm{AO}$ yang belum terhumifikasi. Asam organik yang belum terhumifikasi secara kimia sama efektifnya dengan bahan humat, namun karena konsentrasinya rendah, pengaruhnya kalah oleh AH dan AF (Baker, 1973; Singer dan Navrot, 1976 dalam Tan, 1986).

Sisa tanaman seperti pangkasan titonia sewaktu mengalami perombakan (dekomposisi) akan menghasilkan AO. Di samping dapat melarutkan unsur hara, AO dalam konsentrasi tinggi dapat menghambat pertumbuhan tanaman. Daya hambat akan lebih besar bila dekomposisi terjadi pada tanah tergenang. Menurut Patrick (1971) dan Ponnamperuma (1978) bila dekomposisi terjadi dalam keadaan kurang Oksigen $\left(\mathrm{O}_{2}\right)$ maka akan terbentuk asam-asam yang meracun seperti asam asetat, asam laktat, asam butirat, asam format, senyawasenyawa fenol seperti p-hidroksi benzoat, asam ferulat, asam siringat, asam vanilat dan lain-lain.

Menurut Takajima 1960, (dalam Tsutsuki, 1984) AO yang sifat asamnya berasal hanya dari gugus $-\mathrm{COOH}$ termasuk pada asam-asam karboksilat (asam-asam lemak volatil). Asam-asam karboksilat ini dapat terbentuk melalui dekomposisi karbohidrat dan protein dalam tanah tergenang. Janis AO yang terdeteksi pada tanah sawah adalah asam asetat $>$ asam butirat > asam fumarat $>$ asam propionat $>$ asam valerat > asam suksinat dan asam laktat. Acharya (1935 dalam Tsutsuki, 1984) menyatakan bahwa proses dekomposisi BO (jerami) pada kondisi anaerob, pada tahap pertama terbentuk AO. Asam-asam organik yang terdeteksi dalam penelitian mereka adalah asam asetat, dan asam butirat, serta terdeteksi pula gas $\mathrm{CO}_{2}$, dan gas metan.

Asam-asam organik yang terdapat gugus $-\mathrm{COOH}$ dan $\mathrm{OH}$ fenolik dalam molekulnya termasuk asam-asam fenolat. Komponen BO utama dalam pembentukan 
asam fenolat adalah lignin. Lignin akan mengalami biodegradasi dengan bantuan cendawan Basidiomicetes, Hendersonula stachybotrysatra, dan S. chartarum serta Aspergillus sydowi dalam proses dekomposissinya. Pada tingkat permulaan degradasi lignin oleh cendawan dipandang sebagai kebalikan sintesis lignin. Pada tingkat yang lebih lanjut, degradasi lignin akan menghasilkan bermacam-macam asam aromatik dengan berat molekul (BM) rendah dan aldehida termasuk vanilin dan asam vanilat. Hasil biodegradasi lainnya adalah asam siringat, $\mathrm{p}$-hidroksibenzaldehida, asam p-hidroksibenzoat, asam prokatekuik, dan asam galik (Stevenson, 1994).

Dari hasil penelitian Prasetyo (1996), konsentrasi AO dalam kadar yang tinggi akan menghambat pertumbuhan akar tanaman padi umur 2 minggu. Asam butirat akan menghambat pertumbuhan akar tanaman padi pada konsentrasi 125 - 200 $\mathrm{mg} \mathrm{l}^{-1}\left(1,42-2,27 \mathrm{mM} \mathrm{l}^{-1}\right)$, asam asetat pada kadar $150300 \mathrm{mg} \mathrm{l}^{-1}\left(2,5-5,0 \mathrm{mM} \mathrm{l}^{-1}\right)$ dan pertumbuhan tanaman relatif baik pada kadar asam asetat kurang dari $100 \mathrm{mg} \mathrm{l}^{-1}$ $\left(1,67 \mathrm{mM} \mathrm{l}^{-1}\right)$. Untuk asam suksinat sampai kadar $400 \mathrm{mg} \mathrm{l}^{-1}\left(3,39 \mathrm{mM} \mathrm{l}^{-1}\right)$ akar tanaman padi masih dapat berkembang, namun mulai terhambat pada kadar $300 \mathrm{mg} \mathrm{l}^{-1}\left(2,54 \mathrm{mM} \mathrm{l}^{-}\right.$ ${ }^{1}$ ), sedangkan untuk asam propionat mulai menghambat pertumbuhan akar tanaman padi pada konsentrasi $100 \mathrm{mg} \mathrm{l}^{-1}(1,35 \mathrm{mM}$ $\left.1^{-1}\right)$. Selanjutnya Prasetyo (1997) berpendapat bahwa pada konsentrasi asam karboksilat murni dengan kadar kecil dari 50 $\mathrm{mg}^{-1}$ tanaman padi umur 2 minggu masih dapat beradaptasi.

Lebih lanjut Prasetyo (1996) melaporkan bahwa, pertumbuhan akar tanaman padi dalam larutan asam fenolat murni sampai $50 \mathrm{mg} \mathrm{l}^{-1}$ masih lebih panjang daripada tanpa penggunaan larutan asam fenolat. Pertumbuhan akar tanaman relatif baik bila kadarnya kurang dari $50 \mathrm{mg}^{-1}$ $\left(0,31 \mathrm{mM} \mathrm{l}^{-1}\right)$. Pertumbuhan akar tanaman padi umur 2 minggu akan terhambat oleh asam p-kumarat dan asam vanilat bila kadarnya sekitar $100 \mathrm{mg} \mathrm{l}^{-1}$. Di lain pihak, Ponnamperuma (1978) menyatakan bahwa, keracunan asam organik pada tanaman padi tidak mungkin terjadi pada tanah dengan $\mathrm{pH}$ mendekati netral. Sebelumnya Takijima dan Sakuma (1961 dalam Situmorang dan
Sudadi, 2001) mengemukakan bahwa berdasarkan kinetik, pembentukan AO dalam larutan dengan waktu yang singkat setelah penggenangan, hanya sedikit mempengaruhi pertumbuhan tanaman padi.

Supriyadi (2003) serta Gusnidar dan Prasetyo (2008) melaporkan bahwa, titonia mengandung 2,1-3,43\% N; 0,31\% P; 38,547,89 \% C-total; 9,8 \% lignin; 3,3\% polifenol; 2,1-4,16 \% K; 1,14-1,30 \% Ca; 0,60-0,78 \% Mg. Nisbah $\mathrm{C} / \mathrm{N}$ dan $\mathrm{C} / \mathrm{P}$ masing-masing 19 dan 128 . Lebih lanjut Supriyadi (2003) menemukan AO dalam titonia antara lain $32 \mathrm{mg} \mathrm{kg}^{-1}$ asam sitrat, 11 $\mathrm{mgkg}^{-1}$ asam oksalat, $48 \mathrm{mgkg}^{-1}$ asam suksinat, $17 \mathrm{mgkg}^{-1}$ asam asetat, $75 \mathrm{mg} \mathrm{kg}^{-1}$ asam malat, $49 \mathrm{mgkg}^{-1}$ asam butirat, 31 $\mathrm{mgkg}^{-1}$ asam propionat, $20 \mathrm{mgkg}^{-1}$ asam phtalat, dan $69 \mathrm{mgkg}^{-1}$; asam benzoat. Jenis AO dari dekomposisi titonia tersebut berpotensi untuk meningkatkan kelarutan $P$. Pada kondisi anaerob seperti pada tanah sawah apakah pemberian titonia akan menghasilkan AO dalam konsentrasi yang lebih tinggi dan berpotensi meracun serta menghambat pertumbuhan bibit padi belum dilaporkan, sehingga perlu dipelajari dalam suatu penelitian.

Tujuan penelitian adalah untuk menentukan cara pemberian titonia yang tepat serta hubungannya dengan kadar asamasam organik tanah sawah.

\section{BAHAN DAN METODE}

Percobaan dilakukan di Laboratorium Tanah Fakultas Pertanian dan Laboratorium Fisiko Kimia Fakultas Farmasi Universitas Andalas Padang. Percobaan berlangsung sejak Januari sampai Agustus 2005. Contoh tanah komposit pada kedalaman $\quad 0-20 \mathrm{~cm}$ diambil di persawahan yang ditanami secara intensif di Kenagarian Sicincin, Kecamatan 2 x 11 Enam Lingkung, Kabupaten Padang Pariaman. Biomasa titonia diambil di lokasi yang sama, dengan cara memangkas $50 \mathrm{~cm}$ dari pucuknya. Beberapa bahan kimia murni digunakan untuk analisis tanah, titonia dan asam-asam organik. Percobaan terdiri dari 3 seri cara pemberian titonia yaitu; $\mathrm{A}_{1}=$ Disebar di atas tanah, langsung digenangi; $\mathrm{A}_{2}=$ Disebar di atas tanah 3 minggu, 
Tabel 1. Hasil analisis titonia yang digunakan untuk penelitian

\begin{tabular}{llr}
\hline Parameter & Satuan & \multicolumn{1}{l}{ Nilai } \\
\hline Kadar air biomassa & $(\%)$ & 400,00 \\
Komposisi kimia & & \\
N-total & $(\%)$ & 3,43 \\
P-total & $(\%)$ & 0,31 \\
K-total & $(\%)$ & 4,16 \\
C-total & $(\%)$ & 47,89 \\
Ca-total & $(\%)$ & 1,14 \\
Mg-total & $(\%)$ & 0,78 \\
Lignin & $(\%)$ & 16,90 \\
Selulosa & $(\%)$ & 52,99 \\
Asam-asam organik titonia segar & & \\
- benzoat & $\left(\mathrm{mg} \mathrm{kg}^{-1}\right)$ & 7,36 \\
- propionat & $\left(\mathrm{mg} \mathrm{kg}^{-1}\right)$ & 13,90 \\
- sitrat & $\left(\mathrm{mg} \mathrm{kg}^{-1}\right)$ & 118,75 \\
- pro-katecuat & $\left(\mathrm{mg} \mathrm{kg}^{-1}\right)$ & 182,26 \\
Ratio C/N & & 13,96 \\
Ratio C /P & & 154,50 \\
\hline
\end{tabular}

Tabel 2. Ciri kimia tanah yang digunakan untuk penelitian

\begin{tabular}{|c|c|c|c|}
\hline \multicolumn{2}{|c|}{ Jenis analisis } & Nilai & Kriteria \\
\hline \multicolumn{4}{|c|}{ Tekstur } \\
\hline a. Pasi & $(\%)$ & 47,50 & \\
\hline b. Deb & $(\%)$ & 50,30 & Lempung berdebu \\
\hline c. Liat & $(\%)$ & 2,20 & \\
\hline pH $\mathrm{H}_{2} \mathrm{O}($ & $(1: 2)$ & 6,03 & Agak masam* \\
\hline $\mathrm{KCl}($ & $1: 2)$ & 5,46 & \\
\hline C-organik & $(\%)$ & 4,25 & Tinggi* \\
\hline N-total & $(\%)$ & 0,48 & Tinggi* \\
\hline $\mathrm{KB}$ & $(\%)$ & 31,75 & Rendah* \\
\hline \multicolumn{2}{|c|}{ Ratio $\mathrm{C} / \mathrm{N}$} & 8,85 & Rendah** \\
\hline \multicolumn{2}{|c|}{ P-tersedia $\quad\left(\mathrm{mg} \mathrm{kg}^{-1}\right)$} & 391.90 & Sangat tinggi* \\
\hline & 1230,29 & Sangat tinggi** \\
\hline \multicolumn{2}{|c|}{$\begin{array}{ll}\text { P-potensial } & \left(\mathrm{mg} \mathrm{kg}^{-1}\right) \\
\text { Fe-dd } & \left(\mathrm{mg} \mathrm{kg}^{-1}\right)\end{array}$} & 2,88 & Rendah* \\
\hline \multirow{2}{*}{\multicolumn{2}{|c|}{ 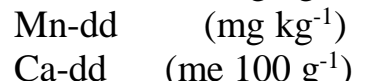 }} & 12,47 & Tinggi** \\
\hline & & 9,03 & Sedang* \\
\hline \multicolumn{2}{|c|}{$\begin{array}{ll}\text { Ca-dd } & \left(\text { me } 100 \mathrm{~g}^{-1}\right) \\
\text { Mg-dd } & \left(\text { me } 100 \mathrm{~g}^{-1}\right)\end{array}$} & 1,74 & Sedang* \\
\hline \multicolumn{2}{|c|}{ K-dd $\quad\left(\right.$ me $\left.100 \mathrm{~g}^{-1}\right)$} & 0,47 & Sedang* \\
\hline \multirow{2}{*}{\multicolumn{2}{|c|}{$\begin{array}{ll}\text { Na-dd } & \left.\text { (me } 100 \mathrm{~g}^{-1}\right) \\
\text { KTK } & \left.\text { (me } 100 \mathrm{~g}^{-1}\right)\end{array}$}} & 1,00 & Tinggi* \\
\hline & & 38,55 & Tinggi* \\
\hline
\end{tabular}

digenangi; $\mathrm{A}_{3}=$ Disebar dan diinkubasi kapasitas lapang 3 minggu, digenangi. Masing-masing seri diberi 5 dosis titonia $(0,000 ; 1,250 ; 2,500 ; 3,750 ;$ dan 5,000$) \mathrm{g}$ setara titonia kering $\mathrm{kg}^{-1}$ tanah. Konversi berat kering keberat segar dihitung berdasarkan KKA titonia $=5$. Kualitas titonia yang digunakan seperti pada Tabel 1, dan ciri kimia tanah pada Tabel 2.
Sebanyak 45 pot percobaan disiapkan dan diisi setara $1 \mathrm{~kg}$ tanah kering mutlak (TKM). Selanjutnya titonia dicincang sekitar $1-3 \mathrm{~cm}$, kemudian tanah tersebut diberi titonia sesuai dengan perlakuan dan digenangi dengan cara yang telah ditetapkan. Penggenangan dilakukan setinggi $5 \mathrm{~cm}$ dan dipertahankan selama percobaan dengan jalan menambah 
kekurangan tinggi air setiap hari. Pengamatan tanah dilakukan pada 6 , 9, dan 12 minggu setelah perlakuan (MSP). Sebelum sampel tanah diambil, tanah diaduk, kemudian dibiarkan 15 menit. Kemudian diambil sampel tanah sebanyak $50 \mathrm{~g}$, diletakkan di atas selembar kain kasa. Air yang terbawa bersama tanah diperas dan ditampung untuk dianalisis AO. Prosedur analisis AO tersebut disajikan berikut ini.

Persiapan fase gerak (Eluent)

Aquabides disaring dengan kertas saring sellulose nitrat $0,45 \mathrm{~m}$; diameter 47 mm dengan bantuan pompa vakum. Methanol disaring dengan Whatman Membrane filters PTFE ukuran pori (pore size) 0,5 m dengan bantuan pompa vakum. Selanjutnya aquabides dan methanol dicampur dan digesing dengan Ultrasonic Bath selama 30 menit pada suhu $25^{\circ} \mathrm{C}$.

Preparasi larutan standar (Supriyadi, 2003)

Larutan standar dibuat dengan melarutkan asam organik murni (> $96 \%$ ); yaitu asam benzoat, phtalat, suksinat, galat, salisilat, malat, oksalat, sitrat, pro katecuat, vanilat, p-kumarat, dan lain-lain dalam aquabides (air bebas ion) yang telah di saring dengan filter sellulose nitrat, $\mathrm{pH}$ akhir larutan standard diatur menjadi 4,5 dengan penambahan $\mathrm{NaOH} 0,1 \mathrm{~N}$. Masing-masing standard dibuat dengan konsentrasi 50 ppm (tergantung penampilan peak yang muncul).

Persiapan analisis asam-asam or ganik

Tanah dan air atau ekstrak tanaman dimasukkan ke dalam tabung sentrifus, dikocok selama 1 jam, selanjutnya disentrifus dengan kecepatan $2500 \mathrm{rpm}$ selama 15 menit, kemudian disaring dengan kertas saring Whatman 42. Hasil saringan disentrifus dengan kecepatan 10.000 rpm selama 15 menit. Kemudian disaring dengan kertas saring Whatman 42 (Prasetyo, 1996). Hasil saringan sampel disimpan dalam kulkas/lemari pendingin untuk mencegah terjadinya perubahan atau degradasi asam-asam organik.

Untuk dapat diinjeksi ke HPLC, baik standard, maupun sampel disaring dengan Whatman Membrane filters PTFE (Polyprophylene backed) ukuran pori (pore size) $0,2 \mathrm{~m}$ diameter $13 \mathrm{~mm}$.
Analisis asam-asam or ganik

Konsentrasi asam organik dalam ekstrak bahan organik atau tanah, diukur dengan Khromatografi Cair Kinerja Tinggi (KCKT) atau High Performance Liquid Chromatographi (HPLC) Shimadzu model pompa tunggal, detector UV 254, dengan lampu D2 pada panjang gelombang $228 \mathrm{~nm}$. Kolom untuk analisis adalah Sin-Pack CLCODS (m) panjang $25 \mathrm{~mm}$, diameter 6,0 $\mathrm{mm}$ seri PN. 228-17873-92. Pada saat alat dioperasikan, temperatur ruangan $20^{\circ} \mathrm{C}$, fase gerak methanol dan aquabides (perbandingan $3: 7$ ) dengan kecepatan alir (flow rate) $0,5 \mathrm{ml} \mathrm{menit}^{-1}$.

Ekstrak sampel yang akan diukur dengan HPLC dipipet sebanyak $1 \mathrm{ml}$, diencerkan dengan fase gerak menjadi $5 \mathrm{ml}$. Kemudian diambil 0,2 $\mathrm{ml}$ dengan menggunakan alat injeksi (springe) dan diinjeksikan ke HPLC. Identifikasi jenis asam dan konsentrasinya dilakukan dengan membandingkan waktu retensi (time retention) dengan luas area grafik larutan standar dengan ekstrak contoh (Yuwono, Mulja, dan Indrayanto, 1999; Supriyadi, 2003).

\section{HASIL DAN PEMBAHASAN}

Hasil analisis AO pada tanah sawah yang diberi titonia segar dan langsung digenangi disajikan pada Tabel 3, yang disebar di atas tanah selama 3 minggu kemudian digenangi pada Tabel 4, sedangkan yang diberi air sampai kapasitas lapang 3 minggu, kemudian digenangi, pada Tabel 5, sedang total asam fenolat dan karboksilat pada ketiga perlakuan tersebut disajikan pada Gambar 1, dan Gambar 2.

Asam-asam fenolat terdeteksi pada 9 dan 12 minggu setelah perlakuan (MSP), yaitu asam prokatecuat, vanilat dan pkumarat. Asam-asam tersebut berpotensi menjadi racun (allelopati) bagi tanaman pada konsentrasi lebih besar dari $100 \mathrm{mgl}^{-1}$. Dilain pihak asam-asam karboksilat terdeteksi pada 6, 9, dan 12 MSP, yang terdiri dari asam asetat, benzoat, galat, malat, propionat, salisilat, sitrat, suksinat, dan tartarat. Asam-asam ini sangat berguna untuk melarutkan unsur-unsur yang terikat di dalam tanah, terutama sekali $\mathrm{P}$. 
Tabel 3. Kadar asam-asam karboksilat dan fenolat pada tanah sawah Sicincin yang diberi titonia, langsung digenangi $\left(\mathrm{mg} \mathrm{l}^{-1}\right)$

\begin{tabular}{llllll}
\hline \multirow{2}{*}{ Jenis AO } & \multicolumn{5}{l}{ Dosis titonia $\left(\mathrm{g} \mathrm{kg}^{-1}\right.$ tanah) } \\
\cline { 2 - 6 } & 0,000 & 1,250 & 2,500 & 3,750 & 5,000 \\
\hline 6 MSP & & & & & \\
Karboksilat & & - & - & - & - \\
asetat & - & - & - & - & - \\
benzoat & - & 137,91 & - & - & - \\
galat & - & - & 270,93 & 313,28 & 213,22 \\
malat & - & - & - & - & - \\
salisilat & - & - & 114,54 & 93,60 & 136,99 \\
sitrat & 13,28 & 112,09 & - & - & - \\
tartarat & 226,69 & - & 385,47 & 406,64 & 350,21 \\
$\quad$ Total & 239,97 & 250,00 & & &
\end{tabular}

$\underline{\text { Fenolat }}$

p-kumarat prokatecuat vanilat

Total

9 MSP

$\underline{\text { Karboksilat }}$ asetat benzoat

galat

malat

salisilat

sitrat

tartarat

Total

$\begin{array}{lll}- & - & 40,39 \\ - & 59,92 & - \\ - & - & - \\ - & - & - \\ - & - & - \\ 46,53 & - & - \\ - & - & - \\ 46,53 & 59,92 & 40,39\end{array}$

125,24

-

-

-

-

125,24

Fenolat p-kumarat prokatecuat vanilat

Total 12 MSP

$\underline{\text { Karboksilat }}$ asetat benzoat galat malat salisilat

sitrat tartarat

Total

Fenolat p-kumarat prokatecuat vanilat $-$ Total 424,24 $\quad$ 471,42

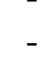

-

$1,54 \quad 3,22$

$\begin{array}{lll}- & 469,38 & 321,69\end{array}$

1,92

484,25

-

- $\quad 3,74$

1,97

39,18

$-$

487,99

472,89

364,09

Total

426,16

471,42

4,23

1,33

3,43

$-$

67,29

$-$

1,33

3,43

4,23

11,29

13,12

11,29 80,41 
Tabel 4. Kadar asam-asam karboksilat dan fenolat pada tanah sawah Sicincin yang diberi titonia pada permukaan tanah 3 minggu, dan digenangi $\left(\mathrm{mgl}^{-1}\right)$.

\begin{tabular}{|c|c|c|c|c|c|}
\hline \multirow[t]{2}{*}{ Jenis AO } & \multicolumn{5}{|c|}{ Dosis titonia $\left(\mathrm{g} \mathrm{kg}^{-1}\right.$ tanah) } \\
\hline & 0,000 & 1,250 & 2,500 & 3,750 & 5,000 \\
\hline \multicolumn{6}{|l|}{$6 \mathrm{MSP}$} \\
\hline \multicolumn{6}{|l|}{ Karboksilat } \\
\hline benzoat & - & - & - & - & - \\
\hline galat & - & - & 114,33 & 119,65 & - \\
\hline malat & 243,36 & 232,13 & - & - & 144,19 \\
\hline propionat & - & - & - & - & - \\
\hline sitrat & 128,32 & 133,94 & 135,67 & 130,15 & 177,91 \\
\hline suksinat & - & - & - & - & - \\
\hline Total & 371,68 & 366,07 & 250,00 & 249,80 & 322,10 \\
\hline \multicolumn{6}{|l|}{ Fenolat } \\
\hline p-kumarat & - & - & - & - & - \\
\hline prokatecuat & - & - & - & - & - \\
\hline vanilat & - & - & - & - & - \\
\hline Total & - & - & - & - & - \\
\hline \multicolumn{6}{|l|}{$9 \mathrm{MSP}$} \\
\hline \multicolumn{6}{|l|}{ Karboksilat } \\
\hline benzoat & - & - & - & - & - \\
\hline galat & - & 185,91 & 127,73 & 127,71 & 143,08 \\
\hline malat & - & - & - & - & - \\
\hline propionat & - & - & - & - & - \\
\hline $\begin{array}{l}\text { sitrat } \\
\text { suksinat }\end{array}$ & - & 4,21 & 114,43 & 126,86 & $\begin{array}{c}108,05 \\
3,64\end{array}$ \\
\hline Total & - & 190,12 & 242,16 & 254,57 & 254,77 \\
\hline \multicolumn{6}{|l|}{ Fenolat } \\
\hline p-kumarat & - & - & - & - & - \\
\hline prokatecuat & - & - & - & - & - \\
\hline vanilat & - & 5,03 & - & - & - \\
\hline Total & - & 5,03 & - & - & - \\
\hline \multicolumn{6}{|l|}{$12 \mathrm{MSP}$} \\
\hline$\overline{\text { benzoat }}$ & - & 4,70 & - & - & - \\
\hline galat & - & - & - & - & - \\
\hline malat & 184,01 & 382,62 & 415,31 & 265,95 & 424,90 \\
\hline propionat & 3,39 & - & - & - & 5,16 \\
\hline sitrat & 103,11 & 53,99 & 39,86 & 57,78 & 32,39 \\
\hline suksinat & - & - & - & - & - \\
\hline Total & 290,51 & 441,31 & 455,17 & 323,73 & 462,45 \\
\hline \multicolumn{6}{|l|}{ Fenolat } \\
\hline$\overline{\text { p-kumarat }}$ & - & - & - & - & - \\
\hline prokatecuat & 102,99 & - & - & 80,05 & - \\
\hline vanilat & - & - & - & 16,28 & - \\
\hline Total & 102,99 & - & - & 96,33 & - \\
\hline
\end{tabular}


Tabel 5. Kadar asam-asam karboksilat dan fenolat pada tanah sawah Sicincin yang diinkubasi dengan titonia kapasitas lapang 3 minggu, dan digenangi $\left(\mathrm{mgl}^{-1}\right)$

\begin{tabular}{|c|c|c|c|c|c|}
\hline \multirow[t]{2}{*}{ Jenis AO } & \multicolumn{5}{|c|}{ Dosis titonia $\left(\mathrm{g} \mathrm{kg}^{-1} \tan a h\right)$} \\
\hline & 0,000 & 1,250 & 2,500 & 3,750 & 5,000 \\
\hline \multicolumn{6}{|l|}{$6 \mathrm{MSP}$} \\
\hline \multicolumn{6}{|l|}{ Karboksilat } \\
\hline benzoat & - & - & - & - & - \\
\hline galat & 164,66 & 120,39 & 169,22 & 187,71 & 183,70 \\
\hline malat & - & - & - & - & - \\
\hline propionat & - & - & - & - & - \\
\hline salisilat & - & - & - & - & - \\
\hline sitrat & 85,34 & 129,61 & 80,78 & 62,29 & 66,30 \\
\hline tartarat & - & - & - & - & - \\
\hline Total & 250,00 & 250,00 & 250,00 & 250,00 & 250,00 \\
\hline \multicolumn{6}{|l|}{ Fenolat } \\
\hline p-kumarat & - & - & - & - & - \\
\hline prokatecuat & - & - & - & - & - \\
\hline Total & - & - & - & - & - \\
\hline \multicolumn{6}{|l|}{9 MSP } \\
\hline \multicolumn{6}{|l|}{ Karboksilat } \\
\hline benzoat & - & - & - & - & 4,00 \\
\hline galat & 149,68 & - & 130,58 & - & - \\
\hline malat & - & - & - & - & - \\
\hline propionat & - & - & - & - & - \\
\hline salisilat & - & - & 5,34 & - & - \\
\hline sitrat & 66,19 & 248,70 & 83,18 & 40,38 & 95,39 \\
\hline tartarat & 30,54 & - & 30,91 & 206,87 & 150,61 \\
\hline Total & 246,41 & 248,70 & 250,01 & 247,25 & 250,00 \\
\hline \multicolumn{6}{|l|}{ Fenolat } \\
\hline p-kumarat & - & - & - & - & - \\
\hline prokatecuat & - & - & - & - & - \\
\hline Total & - & - & - & - & - \\
\hline \multicolumn{6}{|l|}{$12 \mathrm{MSP}$} \\
\hline \multicolumn{6}{|l|}{ Karboksilat } \\
\hline benzoat & - & 1,04 & - & - & - \\
\hline galat & 238,99 & - & - & - & - \\
\hline malat & 10,41 & 489,51 & 448,22 & 392,97 & 370,21 \\
\hline propionat & - & - & - & 3,62 & 3,69 \\
\hline salisilat & - & - & - & - & - \\
\hline sitrat & 2,57 & 4,21 & 24,60 & 49,90 & 61,21 \\
\hline tartarat & - & - & - & - & - \\
\hline Total & 251,97 & 494,76 & 472,82 & 446,49 & 435,11 \\
\hline \multicolumn{6}{|l|}{ Fenolat } \\
\hline p-kumarat & - & - & - & - & - \\
\hline prokatecuat & - & - & - & - & - \\
\hline Total & - & - & - & - & - \\
\hline
\end{tabular}



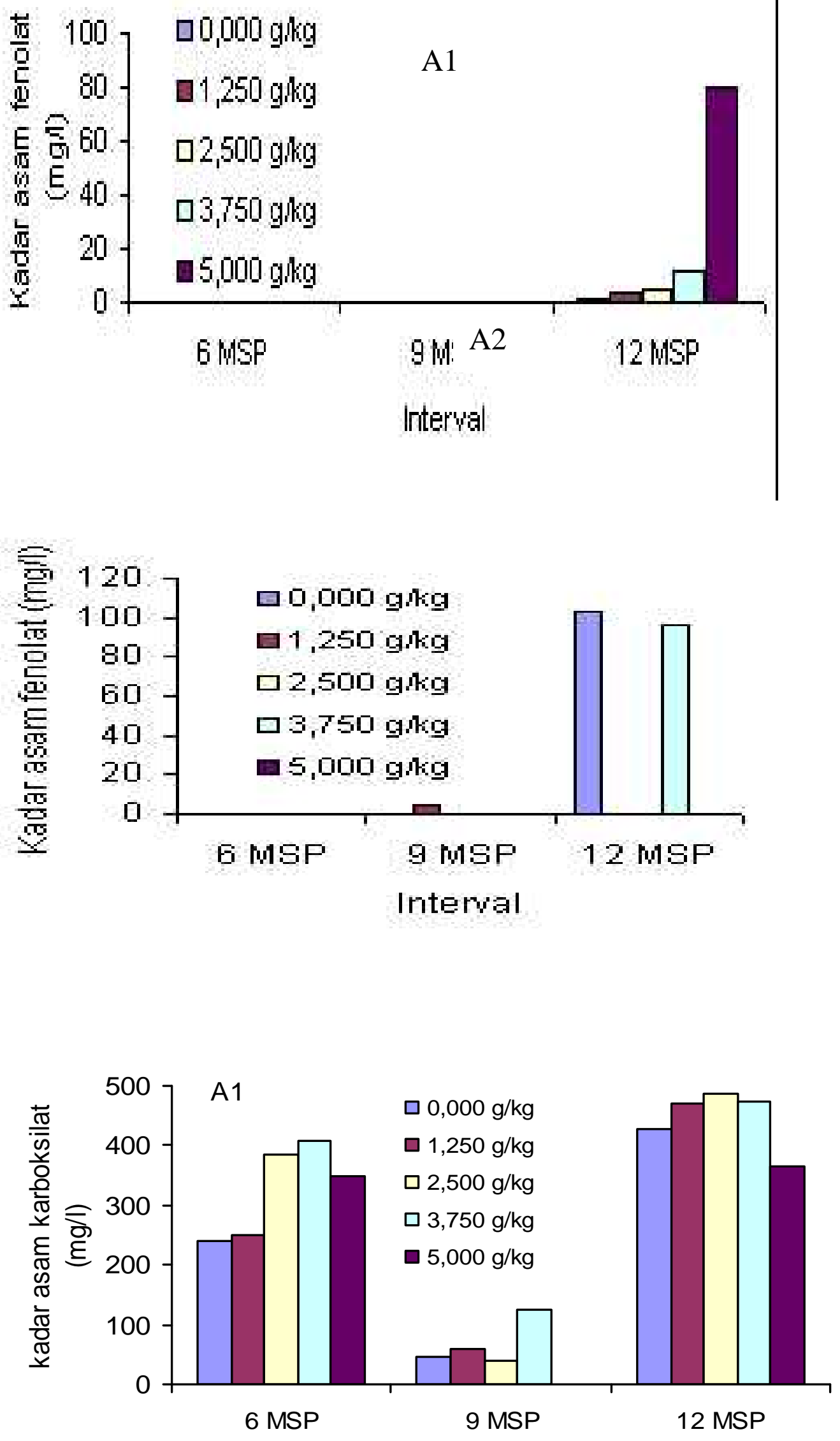


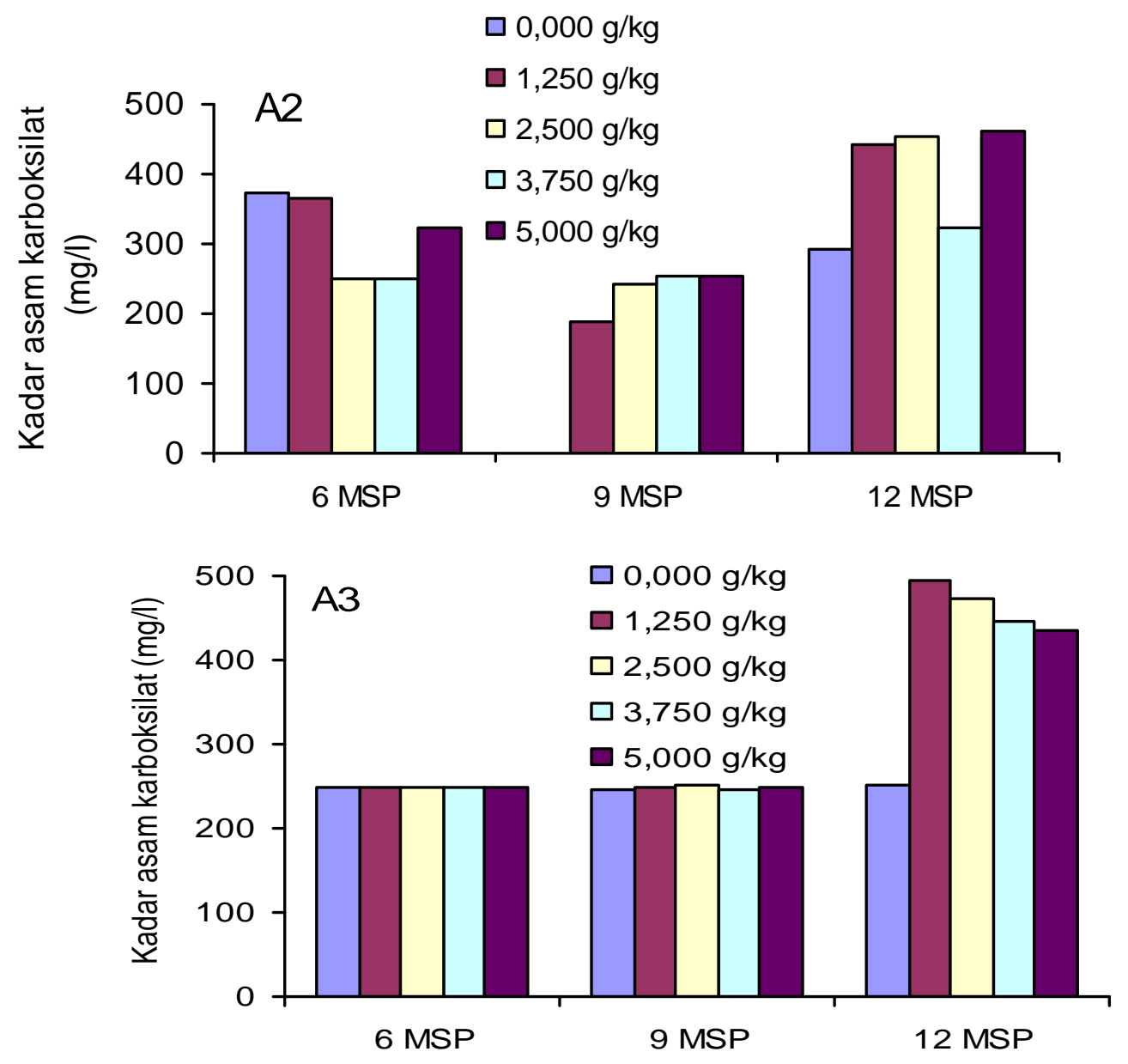

Gambar 2. Histogram total asam karboksilat pada tanah sawah Sicincin yang diberi titonia $\left(\mathrm{A}_{1}=\right.$ Langsung digenangi; $\mathrm{A}_{2}=$ Disebar di atas tanah 3 minggu,digenangi; $A_{3}=$ Diinkubasi kapasitas lapang 3 minggu, digenangi)

Gambar 1 dan Gambar 2, menunjukkan bahwa kadar asam-asam karboksilat lebih tinggi dibandingkan asam-asam fenolat, bahkan asam fenolat tidak terdeteksi sama sekali pada perlakuan yang diinkubasi pada kapasitas lapang, kemudian digenangi $\left(\mathrm{A}_{3}\right)$. Kadar asam karboksilat yang lebih tinggi, dapat disebabkan oleh tingginya kandungan selulosa pada titonia yang digunakan yaitu sebesar 52,99\% dibandingkan lignin hanya sebesar 16,90 \% (Tabel 1). Menurut Novriansyah, Sabiham, Rachim, dan Adjuwana (2000), kandungan asam-asam fenolat tanah erat kaitannya dengan lignin, sedangkan asam-asam karboksilat berkaitan dengan kandungan selulosa. Selulosa lebih cepat terombak dibandingkan lignin.

Dari kelompok karboksilat, yang banyak ditemukan dalam konsentrasi tinggi pada perlakuan yang langsung digenangi $\left(\mathrm{A}_{1}\right)$ adalah asam salisilat $\left(484,25 \mathrm{mg} \mathrm{l}^{-1}\right)$, malat $\left(213,22\right.$ - 471,42 $\left.\mathrm{mg} \mathrm{l}^{-1}\right)$ pada pengamatan 12 MSP (Tabel 3), asam malat (184,01 $424,90 \mathrm{mg} \mathrm{l}^{-1}$ ) pada perlakuan $\mathrm{A}_{2}$ (Dibiarkan 3 minggu di atas tanah, dan digenangi) pada pengamatan 12 MSP (Tabel 4). Pada perlakuan $\mathrm{A}_{3}$ (diinkubasi kapasitas lapang 3 minggu, digenangi) konsentrasi asam tertinggi adalah asam tartarat $\left(206,87 \mathrm{mg} \mathrm{l}^{-1}\right)$, galat $238,99 \mathrm{mgl}^{-1}$, dan malat $(370,21-489$ $\mathrm{mg} \mathrm{l}^{-1}$ ) (Tabel 5). Dari konsentrasi asam karboksilat yang cukup tersebut diharapkan unsur $P$ yang tertimbun dalam sawah intensifikasi akan terlarut dan tersedia bagi tanaman padi. Hal itu diharapkan akan mengurangi penggunaan pupuk $\mathrm{P}$ pada sawah intensifikasi. 
Menurut Hardjowigeno dan Rayes (2001) AO pada tanah anaerob terutama adalah asam alifatik yang mudah menguap (volatile aliphatic acid), seperti asam asetat, asam formiat, asam propionat. Bila tanah digenangi, kandungan asam-asam tersebut mula-mula meningkat $\left(10-40 \mathrm{mM} \mathrm{l}^{-1}\right.$ kemudian menurun hingga $\left.<1 \mathrm{mM} \mathrm{l}^{-1}\right)$ dalam beberapa minggu kemudian. Perubahan tersebut dipengaruhi oleh sifat tanah, sifat dan kandungan bahan organik, serta suhu. Tanah berpasir dengan bahan organik tinggi menghasilkan banyak AO terutama pada suhu $<20^{\circ} \mathrm{C}$. Kadar AO akan lebih tinggi pada suhu rendah. Konsentrasi AO beberapa minggu setelah penggenangan akan menurun, akibat dekomposisi asam tersebut.

Pemberian titonia juga menghasilkan AO fenolat pada tanah sawah, tetapi dalam konsentrasi rendah yaitu berkisar antara $1,33-80,41 \mathrm{mgl}^{-1}$ pada 12 MSP untuk seri $\mathrm{A}_{1}$ (Titonia disebar di atas tanah dn langsung digenangi) dan 96,33 102,99 untuk seri $\mathrm{A}_{2}$ (Tabel 3, dan 4 serta Gambar 1). Pada perlakuan yang diinkubasi pada kapasitas lapang selama 3 minggu, kemudian digenangi $\left(\mathrm{A}_{3}\right)$ keberadaan asam fenolat tidak terdeteksi (Tabel 5), karena asam fenolat yang terbentuk langsung teroksidasi. Dengan kata lain cara pemberian $\mathrm{A}_{3}$ lebih aman, dari pada dua cara yang lain.

Disisi lain, nampaknya fenol baru terbentuk pada 12 MSP, karena lignin lebih lama terdekomposisi dari pada selulosa, sehingga pada 12 MSP tersebut lebih banyak melepaskan asam-asam fenolat. Menurut Rao (1994) dan Stevenson (1994) kandungan lignin yang tinggi akan menghambat proses mineraliasi, karena lignin merupakan polimer pada jaringan tanaman berkayu, sehingga jaringan tanaman menjadi keras dan sukar untuk dirombak oleh mikroorganisme tanah. Akibatnya senyawa ini banyak terakumulasi dalam tanah dan merupakan komponen BO utama dalam pembentukan asam-asam fenolat melalui proses biodegradasi. Pada Tabel 1, titonia mengandung lignin yang rendah $(16,90 \%)$. Oleh karena itu, proses dekomposisi akan berjalan lancar.

Titonia juga mengandung selulosa sebesar 52,99 \% (Tabel 1). Selulosa merupakan komponen penyusun BO yang mudah lapuk karena merupakan bagian dari karbohidrat. Karbohidrat adalah penyusun utama jaringan tumbuhan. Selulosa lebih mudah lapuk dibandingkan dengan lignin. Urutan kecepatan melapuk dari komponen penyusun BO adalah sebagai berikut: protein $>$ hemiselulosa > selulosa > lignin. Dekomposisi bahan organik yang mengandung selulosa terutama dalam keadaan anaerob akan menghasilkan asamasam karboksilat seperti asam asetat, asam butirat, asam propionat dan asam sitrat (Watanabe dan Roger 1985).

Dari hasil analisis asam-asam fenolat (Tabel 3, 4, dan 5), serta Gambar 1 dan 2, ternyata cara pemberian titonia tersebut hanya menghasilkan asam fenolat paling tinggi sekitar $100 \mathrm{mg} \mathrm{l^{-1 }}\left(\mathrm{A}_{2}\right)$. Prasetyo (1996) melaporkan bahwa asamasam fenolat yang meracun tanaman padi bila konsentrasi $>100 \mathrm{mgl}^{-1}$. Oleh karena itu, cara pemberian titonia yang diaduk dengan tanah selama 3 minggu pada kapasitas lapang adalah cara yang terbaik dalam memperoleh asam-asam organik yang bermanfaat dan diharapkan dapat melarutkan unsur hara sehingga akan memperbaiki pertumbuhan tanaman padi. Harapan ini dapat disokong dengan hasil penelitian Naim (1982) pemberian air untuk pertumbuhan, perkembangan akar, serapan hara dan produksi yang lebih tinggi tanaman padi cukup diberi air sampai kapasitas lapang. Kasim (2004) juga menyarankan bahwa pemberian air selama pertumbuhan vegetatif tanaman padi cukup dalam kondisi lembab, agar perakaran tanaman mudah mengambil oksigen dan mempercepat serta memperbanyak pertumbuhan anakan, serta produksi dapat ditingkatkan.

\section{KESIMPULAN}

Dalam pemanfaatan titonia sebagai pupuk alternatif untuk padi sawah, cara pemberian yang tepat berbagai dosis titonia dengan tanah sawah adalah diaduk dan diinkubasi dengan tanah pada kapasitas lapang selama 3 minggu, kemudian digenangi. Dekomposisi titonia pada tanah sawah dengan perlakuan tersebut menghasilkan asam-asam organik karboksilat seperti asam galat, sitrat, tartarat, malat, dan benzoat. 
Asam karboksilat yang dominan terdeteksi adalah asam malat (184-489 $\mathrm{mgl}^{-1}$ ), dan asam fenolat tidak terdeteksi sama sekali.

\section{DAFTAR PUSTAKA}

Gusnidar, dan T. B. Prasetyo. 2008. Pemanfaatan Tithonia diversifolia pada tanah sawah yang dipupuk $P$ secara starter terhadap produksi serta serapan hara $\mathrm{N}$, $\mathrm{P}$, dan $\mathrm{K}$ tanaman padi. J. Tanah. Trop., vol. 13. 3: 209-216.

Hardjowigeno, Sarwono dan M. Luthfi Rayes. 2001. Tanah Sawah. Program Pascasarjana IPB. Bogor. 155 halaman.

Hardjowigeno, Sarwono. 2003. Ilmu Tanah. Akademika Pressindo. Jakarta. 286 halaman.

Kasim, M. 2004. Manajemen penggunaan air: Meminimalkan penggunaan air untuk meningkatkan produksi padi sawah melalui sistim intensifikasi padi (The System of Rice Intensification- SRI). Pidato pengukuhan sebagai guru besar tetap bidang ilmu Fisiologi Tumbuhan, pada Fakultas Pertanian Universitas Andalas Padang. 42 halaman.

Naim, T. 1982. Pengaruh pemberian Silikon pada tiga kelengasan tanah terhadap pertumbuhan dan produksi padi (O ryza sativa L). Tesis Magister, Fakultas Pascasarjana IPB. Bogor. 101 halaman.

Novriansyah, H., S. Sabiham., Rachim dan H. Adjuwana. 2000. Studi kandungan asam-asam fenolat pada tanah gambut Kalimantan Tengah. J. Tanah. Trop., vol. 2. 11:69-73.

Patrick, Z. A. 1971. Phytotoxic subtances associated with the decomposition in soil of plant residues. Soil Sci. 111- 1318.

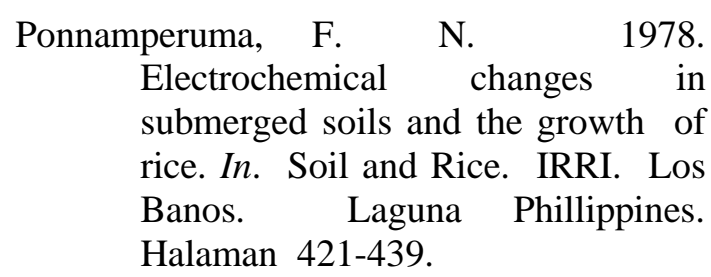

Prasetyo, T. B. 1996. Perilaku asam-asam organik meracun paa tanah gambut yang diberi garam $\mathrm{Na}$ dan beberapa unsur mikro dalam kaitannya dengan hasil padi. Disertasi Doktor. Program Pascasarjana, IPB. Bogor. 190 halaman.

Prasetyo, T. B. 1997. Studi asamasam fenolat pada tanah gambut yang diberi garam $\mathrm{Na}$ dan unsur mikro $\mathrm{Cu}$ dalam kaitannya dengan hasil padi. Makalah seminar bulanan. Jurusan Tanah Fakultas Pertanian Unand. Padang. 16 halaman.

Situmorang, R., dan Untung Sudadi. 2001. Tanah sawah. Bahan kuliah S1. Jurusan Tanah. Fakultas Pertanian, IPB. Bogor. 105 halaman.

Stevenson, F. J. 1994. Humus Chemistry, Genesis, Composition, Reactions. $2^{\text {nd }}$. Ed. John Wiley and Sons, N. Y. 496 halaman.

Subba Rao, N. S. 1994. Mikroorganisme Tanah dan Pertumbuhan Tanaman. Terjemahan oleh Susilo, Herawati. Edisi Kedua. UI Press. Jakarta. 353 halaman.

Supriyadi. 2003. Studi penggunaan biomassa Tithonia diversifolia dan Tephrosia candida untuk perbaikan $\mathrm{P}$ dan hasil jagung (Zea mays) di Andisol. Disertasi Doktor. Program Pascasarjana Unibraw. Malang. 172 halaman.

Tan, K. H. 1986. Degradasi mineral tanah oleh asam organik. Dalam Huang, P. M. dan M. Schnitzer (ed). 1997. Interaksi mineral tanah 
dengan organik alami dan mikroba. Terjemahan oleh Goenadi, D. Gadjah Mada University Press. Yogyakarta. Halaman 1-40.

Tan, K. H. 2003. Humic Matter in Soil and Environment. Marcel Dekker, Inc. N. Y. 386 halaman.

Team 4 Architechs and consulting Engineers, bekerjasama dengan Fakultas Pertanian Universitas Andalas. 1983. Survey tanah dan kesesuaian lahan Balai Penelitian Tanaman Pangan Sukarami. Fakultas Pertanian Universitas Andalas. 101 halaman.

Tsutsuki, K. 1984. Volatile products and low moleculer weight phenolic products of the anaerobic decomposition of organic matter. In Organic Matter and Rice. IRRI. Los Banos, Phillippines. Halaman 329-344.

Watanabe, I., dan P. A. Roger. 1985. Ecology of flooded rice fields. In Wetland Soil., characterization, classification, and utilization. IRRI. Los Banos. Laguna. Manila. Phillippines. Halaman 229-246.

Yuwono, M., M. Mulja., dan G. Indrayanto. 1999. HPLC. Unit Layanan Konsultasi dan kerjasama Penelitian, Fakultas Farmasi Universitas Airlangga. Surabaya. 65 halaman. 